\title{
PENGARUH COVID-19 TERHADAP KONDISI SOSIAL BUDAYA DI KOTA MALANG DAN KONSEP STRATEGIS DALAM PENANGANANNYA
}

\author{
Heylen Amildha Yanuarita ${ }^{1)}$ \\ Sri Haryati ${ }^{2}$ \\ Fakultas Ilmu Sosial dan Ilmu Politik, Universitas Kadiri ${ }^{1}$ \\ Email : heylenay@unik-kediri.ac.id \\ Fakultas Ilmu Sosial dan Ilmu Politik, Universitas Kadiri ${ }^{2}$ \\ Email : sriharyati123@unik-kediri.ac.id
}

\begin{abstract}
ABSTRAK
Penelitian ini bertujuan untuk menganalisis bagaimana penyebaran virus corona di Kota Malang dan bagaimana dampaknya terhadap kondisi sosial budaya serta mencari tahu langkah strategis dalam upaya penanganan. Adapun metode penelitian yang digunakan yakni metode studi kuantitatif deskriptif dibantu dengan tinjauan studi literatur sederhana yang sesuai dengan materi atau pembahasan penelitian. Populasi dari penelitian adalah seluruh masyarakat Kota Malang dengan penentuan sampel menggunakan teknik purposive sampling kepada pemerintah daerah Kota Malang, pihak yang bertugas di bidang kesehatan di Kota Malang, dan masyarakat sekitar yang ada di Kota Malang. Berdasarkan hasil penelitian, ditemukan bahwa penyebaran COVID-19 di Kota Malang terus mengalami kenaikan dan memberikan dampak sosial budaya ke arah negatif, khususnya setelah diberlakukannya Pembatasan Sosial Berskala Besar (PSBB). Dari mulai tingkat perceraian tinggi, interaksi sosial terbatas, hingga pengaruh sosial pada perempuan dan anak-anak. Maka dari itu, perlu diberlakukan langkah strategis dengan penggunaan demografi sosial berdasarkan penurunan mobilitas sosial masyarakat di Kota Malang.
\end{abstract}

Kata kunci: Dampak Covid-19, sosial budaya, strategi

\begin{abstract}
This study aims to analyze how the spread of the corona virus in Malang City and how it affects socio-cultural conditions and find out strategic steps in handling efforts. The research method used is descriptive quantitative study method assisted by a simple literature study review in accordance with the material or research discussion. The population of this research is all people of Malang City with the determination of the sample using purposive sampling technique to the local government of Malang City, those who are in charge of the health sector in Malang City, and the surrounding community in Malang City. Based on the results of the study, it was found that the spread of COVID-19 in Malang City continued to increase and had a negative socio-cultural impact, especially after the implementation of Large-Scale Social Restrictions (PSBB). Starting from the high divorce rate, limited social interaction, to social influence on women and children. Therefore, it is necessary to implement strategic steps by using social demographics based on decreasing social mobility in Malang City.

Keywords: impact of COVID19, socio-cultural, strategy
\end{abstract}

\section{PENDAHULUAN}

Terhitung sejak Maret 2020, pandemi akibat COVID-19 di Indonesia belum juga berakhir. Mulanya, pada Desember 2019, COVID-19 menjadi misteri yang mengerikan saat terjadi di Wuhan, China. Banyak orang merasakan sesak napas, kejang-kejang, hingga akhirnya tidak sadarkan diri. Penelitian demi penelitian terus 
dilakukan untuk mencari tahu apa sebabnya masyarakat di Kota Wuhan mengalami hal tersebut. Hasil penelitian mengungkap bawa masyarakat telah terinfeksi virus Corona atau SARSCoV-2. Pada kasusnya yang pertama kali di China, virus corona sudah menginfeksi setidaknya 90.308 orang per tanggal 2 Maret 2020. Tak hanya itu, jumlah kematiannya mencapai 3.087 orang atau sekitar 6\%. Sementara jumlah pasien yang sembuh adalah 45.726 orang. Jika dilihat dari struktur virus, coronavirus adalah RNA strain tunggal positif yang bisa menginfeksi saluran pernapasan manusia. Virus ini bersifat sensitif terhadap suhu panas sehingga secara efektif bisa diinaktifkan oleh desinfektan yang mengandung klorin. Tak hanya itu, sumber host atau sumber virus ini diduga berasal dari hewan terutama kelelawar, dan vektor lain seperti tikus bambu, dan musang (Yuliana, 2020).

Sementara itu, WHO (2020) menyatakan bahwa penyebaran virus Corona sangat berkembang dengan pesat. Hal tersebut dibuktikan dengan penyebaran virus yang merambah hampir ke seluruh dunia, termasuk Indonesia. Di Indonesia, khususnya di Kota Malang, Jawa Timur, pandemi COVID-19 terasa begitu lekat. Awal mula kasus di Indonesia, terjadi pada bulan Maret 2020 yang kemudian tumbuh serta menyebar ke daerah-daerah yang ada di Indonesia. Setiap harinya kasus terkonfirmasi positif terinfeksi virus corona terus bertambah. Begitu halnya dengan pasien yang meninggal dunia akibat terinfeksi virus ditambah adanya komplikasi penyakit berat sehingga presentase bertahan jadi lebih sedikit. Adapun total kasus di Indonesia yang mencapai 392.934 pasien terinfeksi, 13.411 pasien meninggal, dan 317.672 pasien yang sembuh (Worldometers, 26/10/2020). Sementara itu, terhitung jumlah kasus total di Jawa Timur pada 26 Oktober 2020 sebanyak 51.217 orang dengan pasien meninggal dunia 3.683, sedangkan pasien sembuh 45.203 orang. Sedangkan jumlah kasus khusus di Kota Malang pada 25 Oktober adalah 1987 untuk kasus terkonfirmasi positif, pasien sembuh 1760 dan pasien meninggal 199 orang (Pemprov Jatim (daring, 2020)).

Fenomena ini membawa petaka bagi kehidupan sosial dan budaya masyarakat khususnya di Kota Malang. Terlebih sejak diberlakukannya social distancing yang kemudian diubah penamaannya menjadi phsyical distancing. Pada pemberlakuannya, masyarakat diimbau agar menjauhi kontak fisik antara satu orang dengan lainnya, selalu berdiam di rumah, menghindari kerumunan, selalu mencuci tangan, hingga selalu memakai masker. Bahkan saat COVID-19 sedang gencarnya, muncul tagar "dirumahaja" di media digital sebagai aksi seruan agar tidak keluar rumah dan menghindari penyebaran virus. Semua kegiatan beralih fungsi dari yang asalnya serba tatap muka, menjadi daring atau dalam jaringan. Ibadah di tempat beribadah ditiadakan sementara, sekolah diliburkan sementara dan belajar online lewat media digital, pegawai kantor yang bekerja dari rumah, bahkan pengaruh terburuknya adalah banyak masyarakat yang kehilangannya sumber penghasilan karena banyak para pegawai yang di-PHK, atau pedagang yang kehilangan pembeli sebab masyarakat harus berdiam diri di rumah.

Berbagai pengaruh tersebut memicu petaka sosial baru bagi masyarakat Kota Malang. Termasuk permasalahan pada tingkat perceraian yang tinggi akibat terhambatnya faktor ekonomi masyarakat sebab pemberlakukan Pembatasan Sosial Berskala Besar (PSBB), kekerasan pada perempuan dan anak, tingkat kriminalistas yang semakin tinggi, pendidikan anak yang tidak biasa, proses adaptasi masyarakat ke 
era new normal yang dianggap sulit, kehamilan yang tidak diinginkan, dan banyak lagi. Gubernur Jawa Timur, Khofifah Indar Parawansa menyebutkan bawa "Kita harus bisa bergandengan tangan untuk mencari solusi efektif atas dampak sosial Covid-19" (Republika: 27/03/2020). Maka dari itu, penelitian kali ini dimaksudkan untuk mencari tahu sudah sejauh mana pengaruh COVID-19 di Jawa Timur khususnya Kota Malang, terhadap kehidupan sosial budaya masyarakat, dan mencari strategi efektif dalam menangani dampak yang ditimbulkannya.

\section{KAJIAN LITERATUR Tentang COVID-19}

COVID-19 atau Corona Virus Disease tahun 2019 merupakan penyakit menular yang disebabkan oleh coronavirus jenis baru. Coronavirus $(\mathrm{CoV})$ adalah keluarga besar dari virus yang bisa menyebabkan berbagai gejala ringan hingga berat. Dari segi gejalanya, keluarga virus ini seringkali menyerang di sistem pernapasan manusia. Setidaknya, terdapat dua jenis coronavirus yang juga pernah menyerang masyarakat Indonesia dan kasus penyebarannya cukup tinggi, yakni East Respiratory Syndrome Coronavirus (SARS-CoV) dan Severe Acute Respiratory Syndrome Coronavirus (SARS-CoV). Dan akhir-akhir ini, muncul coronavirus baru yang dinamakan dengan penyakit COVID-19. Menurut WHO (2020) berdasarkan panduan Surveilans Global, definisi COVID-19 dapat diklasifikasikan menjadi tiga bagian yakni: (1) kasus terduga atau suspect case, (2) kasus probable atau probable case, dan (3) kasus terkonfirmasi atau pasien yang sudah terbukti positif melalui tes laboratorium. Sementara di Indonesia definisi klasifikasi kasus COVID-19 ini dibedakan menjadi: (1) pasien dalam pengawasan atau PdP, (2) orang dalam pemantauan atau OdP, dan (3) orang tanpa gejala atau OTG (Kemenkes RI, 2020).

Menurut Kementerian Kesehatan Republik Indonesia, adapun gejala umum yang akan dirasakan oleh penderita ketika terpapar COVID-19 adalah demam dengan suhu tubuh melebihi 38 derajat Celsius, timbul gejala batuk, sesak napas yang teramat hingga membutuhkan perawatan intens di rumah sakit. Meskipun begitu, setiap gejala yang muncul akan berbeda bagi setiap penderita. Apalagi pada beberapa kasus, gejala bisa diperberat ketika penderita merupakan kalangan usia lanjut serta mempunyai riwayat klinis penyakit penyerta lainnya atau komplikasi penyakit lain misalnya, penyakit paru obstruktif menahun, diabetes, kolesterol tinggi, penyakit jantung. Pun penyebaran virus corona ini akan cepat mengenai seseorang ketika memiliki daya tahan tubuh yang lemah.

Selain perihal gejala, rupanya penyebaran COVID-19 atau virus corona ini tergolong sangat mudah. Salah satu penelitian menyebutkan bahwa dari 1 pasien positif bisa menularkan 3 orang di sekitarnya pada masa inkubasi (Salazar, 2020). Menurut Gugus Tugas Percepatan Penanganan COVID-19 (2020) dalam Ikfina (2020) data pasien COVID-19 jika diklasifikasikan menurut jenis kelamin di Indonesia menunjukkan bahwa jumlah pasien laki-laki yang terinfeksi kasus virus corona lebih tinggi jika dibandingkan dengan perempuan. Begitupun dengan penelitian lainnya yang dilakukan oleh Begley (2020) dalam Ikfina (2020) bahwa adanya kerentanan yang dihadapi oleh laki-laki berkaitan dengan adanya pola pergerakan pihak laki-laki yang lebih banyak dan tinggi berada di luar rumah 
daripada pihak perempuan yang lebih terbatas. Ditambah, selama masa pandemi ini, jika dibandingkan dengan laki-laki, perempuan lebih disiplin dalam menjalani protokol kesehatan seperti menerapkan physical distancing, rajin mencuci tangan, dan menggunakan masker dibandingkan dengan laki-laki. Meski begitu, data kerentanan tersebut belum bisa menjadi dasar terkait kondisi gender yang bisa mempangruhi infeksi COVID-19.

Terkait dengan penelitian ini, terdapat beberapa penelitian terdahulu seperti yang dilakukan oleh (Anung, Casman, \& Nur'aini, 2020) dengan judul Pengaruh Kebijakan Social Distancing Pada Wabah COVID-19 Terhadap Kelompok Rentan di Indonesia, yang menerangkan bahwa dalam hasil penelitiannya fase pandemik yang membutuhkan diterapkannya social distancing bagi masyarakat, kelompok rentan yang terdiri dari anak-anak, ibu hamil, dan lansia menjadi salah satu kelompok yang mengalami dampak terburuk. Selain itu penelitian yang terkait lainnya dilakukan oleh (Dito, Erlina, \& Iskandar, 2020) berjudul Dampak Pandemi COVID-19 Terhadap Perekonomian Indonesia, yang dalam hasil penelitiannya mengemukakan dampak pandemi Covid-19 menyebabkan rendahnya sentimen investor terhadap pasar yang pada akhirnya membawa ke arah cenderung negatif. Langkah-langkah strategis terkait fiscal dan moneter sangat dibutuhkan untuk memberikan rangsangan ekonomi.

Terlepas dari setiap penelitian yang dilakukan oleh berbagai tokoh, namun penyebaran virus corona ini memang dianggap begitu pesat. Akibat pertumbuhan kasus yang terus meluas dan bahkan peningkatkan kasus cukup pesat dan tinggi, akhirnya World Health Organization (WHO) menyatakan bahwa COVID-19 adalah pandemi global. Sementara di Indonesia, Presiden RI, Joko Widodo menyatakan bahwasannya penyebaran virus corona ini adalah sebagai Bencana Nasional (bencan non-alam) terkait dengan adanya perpanjangan status darurat tertentu akibat bencana wabah penyakit. Tentunya dengan penetapan COVID-19 sebagai pandemi global, adalah isyarat bahwa pemerintah dan masyarakat tidak boleh main-main dalam menghadapinya. Akan banyak faktor yang berpengaruh terhadap kondisi masyarakat dan perlunya banyak kebijakan pemerintah dalam mengatasi pandemi ini.

\section{Definisi Dampak Sosial Budaya}

Laju pertumbuhan kasus COVID-19 di Jawa Timur pastinya akan membawa banyak sekali dampak terhadap kehidupan masyarakat. Tidak hanya dampak kesehatan yang banyak menyebabkan masyarakat sakit bahkan meninggal, namun juga dampak di bidang sosial dan budaya masyarakat di Kota Malang, Jawa Timur sejak penyebaran virus corona dan pemberlakukan social atau phsyical distancing, dampak sosial dan budaya di masyarakat semakin terasa. Menurut Poerwadarminto (1980:1085) dampak diartikan sebagai benturan antara dua benda yang mempunyai pengaruh sangat kuat untuk mendatangkan akibat negatif atau positif yang bisa menyebabkan penambahan dalam momentum (pasa) sistem yang mengalami benturan itu. Sementara menurut Kamus Besar Bahasa Indonesia (KBBI.web.id) dampak merupakan sebuah benturan, atau pengaruh kuat yang mendatangkan akibat (baik positif maupun negatif).

Adapun mengenai sosial dan budaya, Enda (2010) menuturkan bahwa sosial adalah cara tentang bagaimana para individu saling berhubungan. Jika dilihat dari arti kemasyarakatan, maka sosial ini akan berarti segala sesuatu yang bertalian dengan sistem hidup secara bersama-sama, atau hidup secara bermasyarakat dari orang atau sekelompok orang yang di dalamnya ada struktur, organisasi hingga 
nilai-nilai dan aspirasi hidup untuk mencapai sesuatu (Ranjabar, 2006). Sedangkan budaya atau disebut juga sebagai kultur, adalah sikap hidup manusia dalam berhubungan secara timbal balik dengan alam, lingkungan hidupnya, yang di dalamnya sudah tercakup segala hasil dari cipta, rasa, karsa, dan karya baik dilihat secara konsep fisik berupa materiil maupun psikologis dan spiritual (Ranjabar, 2006).

Dari pengertian tersebut, bisa disimpulkan bahwa sosial budaya itu adalah segala sesuatu yang diciptakan oleh manusia dengan segala pemikirannya, budi nuraninya dalam hidup bermasyarakat. Atau, bisa dikatakan juga bahwa sosial budaya adalah cara hidup dalam masyarakat. Melihat pada beberapa pengertian tersebut, bisa dikatakan bahwa dampak sosial budaya adalah segala sesuatu yang terjadi akibat adanya benturan atau pengaruh dari suatu hal yang bisa menyebabkan pengaruh negatif maupun positif di bidang sosial atau kemasyarakat dan kultur maupun nilai-nilai kehidupan masyarakat.

\section{Dampak COVID-19}

Perkembangan kasus COVID-19 di Kota Malang, Jawa Timur memperlihatkan sebuah kemajuan yang sangat pesat. Bahkan, meskipun beberapa waktu kasus COVID-19 ini sempat memudar, tetap saja penambahan kasus tetap terjadi. Akibat adanya pandemi COVID-19 ini, tentunya banyak membawa dampak atau pengaruh. Dampak-dampak ini pun berputar di beberapa sektor kehidupan masyarakat. Baik di sektor ekonomi, politik, hingga sosial budaya. Untuk sektor sosial budaya ditandai dengan adanya perubahan sosial budaya bagi masyarakat khususnya di Kota Malang. Baik itu terhadap perilaku sosial masyarakat Kota Malang, misalnya saja yang selalu bersama-sama dalam menjalankan sebuah kegiatan, nilai budaya masyarakat yang mulai luntur karena kurangnya interaksi dan sosialisasi masyarakat akibat pemberlakukan social/physical distancing, hingga kondisi sosial masyarakat yang hampir terpuruk akibat dampak PHK, kurangnya akses turis atau wisatawan di Kota Malang yang terjadi karena pembatasan sosial, hingga penurunan pendapatan masyarakat.

Dampak sosial budaya yang dihadapi oleh masyarakat kota Malang pun tidak terlepas dari dampak ekonomi yang kemudian muncul dan bahkan menjadi salah satu fokus perhatian paling penting. Pada kenyataannya, semenjak pandemi yang terjadi di wilayah Internasional, perekonomian setiap negara yang terdampak mengalami kemerosotan. Begitu halnya di kawasan Kota Malang, banyak masyarakat yang harus kehilangan pekerjaan. Baik karena dilakukan PHK oleh perusahaan, atau karena tidak mendapatkan pemasukan bagi para pelaku usaha atau UKM. Pemberlakukan Pembatasan Sosial Berskala Besar bukan hanya berpengaruh pada masalah sosial di Indonesia, namun juga merambah pada masalah-masalah lain yang diakibatkan oleh pemberlakukan kebijakan tersebut. Dari segi sosialnya, tentu sudah jelas bahwa setiap masyarakat dan antar pihak lain jadi dibatasi proses sosialasiasinya, baik antar sesama keluarga, sesama teman, dan masyarakat lainnya. Kegiatan-kegiatan yang sebelumnya dilaksanakan rutin dan tatapmuka, mendadak jadi ditiadakan, segala macam acara yang sebelumnya sudah direncanakan, mendadakan harus batal. Belum lagi pihak perusahaan yang sudah 
mempersiapkan barang untuk produksi, mendadak harus tutup dan pegawainya dipekerjakan dari rumah.

Selain beberapa dampak tersebut, kehadiran COVID-19 pun berpengaruh pada rendahnya sentimen investor terhadap pasar yang akhirnya berdampak pada kondisi pasar yang kurang stabil (Dito, 2020). Selain itu, Dito (2020) juga menyebutkan bahwa yang paling berdampak besar akibat adanya COVID-19 yakni sektor ekonomi dan perdagangan. Dimana pemberlakukan PSBB menyebabkan ekonomi negara dan daerah jadi melemah. Bahkan sektor ekspor Indonesia ikut mengalami pelemahan. Begitu juga para investor yang terlihat enggan untuk melakukan investasi sebab berada di fase ekonomi sulit. Adapun prospek pertumbuhan ekonomi dunia dan Indonesia 2020 yang berpotensi lebih rendah apabila wabah Covid-19 makin menyebar sehingga memicu penerapan kebijakan restriksi atau social distancing yang lebih ketat oleh berbagai negara, dan tekanan pasar keuangan global berlanjut akibat ketidakpastian yang tinggi (Michael, 2020).

\section{METODE PENELITIAN}

Untuk menghasilkan penelitian yang terkonseptualisasi dengan baik dan terencana, maka diperlukannya proses yang tidak sebentar dan tahap yang tidak sedikit. Adapun tahapan penelitian yang dilakukan penulis untuk meneliti masalah dampak sosial budaya akibat COVID-19 di Kota Malang, Jawa Timur adalah (1) Menentukan berbagai topik pembahasan yang akan diteliti, mencari tahu bagaimana pengaruhnya, dan mencari strategi yang tepat untuk penyelesaian masalah (2) melakukan perumusan terhadap masalah yang ada berupa hipotesis, lengkap dengan semua data yang ada dan menelusuri bagaimana manfaat yang didapat dari penelitian (3) Mencari tahu setiap variabel yang menjadi dampak sosial budaya penyebaran covid-19 di Kota Malang (4) Mengumpulkan setiap data-data yang ada di kawasan Kota Malang, khususnya kawasan yang terdampak COVID19, lalu melakukan analisis menggunakan metode penelitian yang ditentukan (5) Mendapatkan hasil penelitian atau pembahasan bersamaan dengan perumusan kesimpulan.

Dengan beberapa tahapan tersebut, untuk melancarkan prosesnya maka pada penelitian kali ini penulis menggunakan metode penelitian studi kuantitatif deskriptif. Menurut Sugiyono (2016) metode kuantitatif deskriptif adalah metode yang menggunakan pendekatan analisis data sekunder atau metode penelitian yang menggunakan data sekunder sebagai sumber utama. Sebagai penyempurna, maka penelitian juga dibantu dengan adanya tinjauan menggunakan metode studi literatur sederhana sesuai dengan materi atau pembahasan yang sesuai dengan penelitian. Setiap kajian atau literatur yang diperoleh, diproses dan diolah oleh penulis. Baik dengan dikompulasi, dianalisis hingga bisa menghasilkan sebuah kesimpulan mengenai studi literatur tersebut.

Dalam penelitiannya, untuk memberikan nilai akurasi yang tinggi penulis melakukan penelitian terhadap populasi yang ada di masyarakat Kota Malang. Karena adanya keterbatasan penulis dalam mengakses semua populasi, maka ditetapkan sebuah penelitian dengan teknik pengambilan sampel menggunakan purposive sampling atau teknik pengambilan sampel yang khusus dilakukan pada orang-orang atau pihak tertentu yang punya keterkaitan dengan masalah yang 
diteliti sehingga hasilnya akan lebih terfokus. Adapun beberapa pihak atau sampel yang akan diteliti yakni: (1) pemerintah daerah Kota Malang, (2) pihak yang bertugas di bidang kesehatan di Kota Malang (3) masyarakat sekitar yang ada di Kota Malang baik anak-anak, siswa/mahasiswa, orang dewasa maupun orangtua. Ditambah dengan beberapa informasi atau karya tulis ilmiah penunjang yang sudah ada sebelumnya. Penelitian pun dilakukan dengan sistem daring atau dalam jaringan melalui media digital seperti media sosial sesuai dengan kebijakan pemerintah yang mengharuskan adanya jaga jarak atau pembatasan sosial di Indonesia.

\section{HASIL DAN PEMBAHASAN}

\section{Peningkatan Penyebaran Virus Corona}

Hasil penelitian yang didapatkan penulis melalui pengolahan beberapa data menyatakan bahwa penyebaran coronavirus di Indonesia, termasuk pada penyebaran tingkat tinggi. Terhitung sejak ditemukannya kasus awal di Indonesia pada awal Maret 2020, penyebaran terus terjadi hingga ke beberapa wilayah. Di Jawa Timur, perkembangan penyebaran COVID-19 menunjukan angka kematian 9,69\% lebih tinggi jika dibandingkan dengan data nasional yakni 6,51\%. Awal mulanya, kasus penyebaran COVID-19 di Kota Malang terhitung masih kecil dan tidak terlalu banyak terjadi lonjakan.

Namun, sebab kasus pertama yang terjadi dan membuat salah satu penderitanya meninggal dunia, membuat Gubernur Jawa Timur, Khofifah Indra Parawansa memerintahkah untuk menutup dan meliburkan sekolah. Segala macam kegiatan sekolah dan pendidikan dibatalkan, masyarakat yang ingin berpergian jauh apalagi jika harus ke luar kota tidak diizinkan, bahkan sampai diberlakukannya akses penutupan kota yang dimulai tepat pada 18 Maret. Salah satu kluster penyebaran COVID-19 di Jawa Timur, khususnya daerah Malang yang cukup signifikan adalah terjadi di pabrik HM Sampoerna yang mana 2 orang meninggal akibat terinfeksi virus corona, serta 63 pegawai pabrik lainnya dinyatakan positif terinfeksi virus (Kompas, 06/05/2020). Tentu hanya dari satu penyebaran saja, atau dalam kata lain hanya dalam satu kluster, kasus terkonfirmasi positif COVID-19 terus meningkat. Hingga saat ini, penyebaran COVID-19 masih terus terjadi. Untuk penyebaran virus corona dari awal Maret hingga Oktober di Kota Malang, bisa dilihat di Tabel 2.1

\begin{tabular}{cccc}
\hline Tanggal/Bulan & Terkonfirmasi & Meninggal & Pasien Sembuh \\
\hline 31/Maret & 4 & - & 3 \\
30-Apr & 17 & - & 8 \\
31/Mei & 50 & 1 & 17 \\
28/Juni & 197 & 12 & 53 \\
31/Juli & 654 & 54 & 354 \\
28/Agustus & 1.194 & 103 & 761
\end{tabular}


30-Sep

25/Oktober
170

199
1.495

1.76

\section{Tabel 2.1 Perkembangan dan Penyebaran Kasus COVID-19 di Malang}

Sumber: infocovid19.jatimpemprov.go.id

Dari tabel tersebut, bisa dilihat bahwa setiap bulannya penyebaran COVID19 di Kota Malang terus meningkat, baik kasus yang terkonfirmasi positif, hingga pasien yang meinggal. Bisa dilihat dari tabel tersebut, awal mungka angka konfirmasi kasus positif hanyalah 4 orang saja yang merupakan lingkungan awal dari kasus infeksi virus corona yang pertama. Belum ada pasien meninggal ketika kasus pertama ditemukan di Kota Malang, tepatnya pada bulan maret. Sampai bulan Mei 2020 pun, pertumbuhan penderita positif COVID-19 masih tergolong sedikit dan tidak terlalu signifikan. Hingga mulai bulan Juni, pertumbuhan kasus semakin meningkat berkali-kali lipat. Hal ini juga didukung oleh kemunculan kluster baru yang sebelumnya sudah disebutkan yakni dari pabrik HM Sampoerna. Dari waktu ke waktu, peningkatan kasus pun semakin tinggi bersamaan dengan pasien meninggal maupun sembuh.

Perkembangan data ini diakibatkan karena proses penyebaran virus corona yang tergolong sangat cepat dan mudah menular. Kebanyakan kasus penularan terjadi antar manusia (human to human) yang diketahui melalui droplet serta kontak langsung. Setiap droplet yang keluar dari pasien positif, berupa air liur atau percikan air ketika bersin dan batuk, yang kemudian terkena pada saluran napas orang lain, bisa menjadikan orang yang terkena kontak mengalami kasus positif yang sama. Ditambah, masih banyaknya masyarakat yang tidak mengindahkan kebijakan pemerintah untuk menjaga jarak atau kontak langsung, membuat pertumbuhan kasus positif virus corona semakin meningkat.

\section{Dampak Sosial-Budaya yang Ditimbulkan}

Selain menunjukan adanya peningkatan kasus terkonfirmasi positif COVID19 maupun pasien meninggal di Kota Malang, penelitian ini pun memberikan hasil berupa pengaruh-pengaruh yang lebih menjurus ke arah negatif akibat penyebaran virus corona yang tinggi serta setelah diberlakukannya Pembatasan Sosial Berskala Besar. Hasil ini didapatkan setelah melakukan proses wawancara secara digital terhadap beberapa sampel yang dijadikan objek penelitian, juga beberapa karya tulis penunjang. Adapun beberapa dampak sosial dan budaya yang ditemukan pada penelitian ini yang terjadi pada masyarakat Kota Malang adalah sebagai berikut:

\section{a. Dampak Sosial bagi Siswa-Mahasiswa}

Berdasarkan hasil penelitian yang dilakukan khusus pada anak-anak di kawasan Kota Malang, maka dampak sosial yang paling besar adalah terhadap pendidikan anak-anak. Beberapa masalah yang dihadapi oleh anak-anak tersebut seperti berikut:

1. Keterbatasan dalam penguasaan teknologi informasi yang dialami oleh anak-anak ketika diberlakukannya sekolah online. 
2. Tidak semua anak-anak memiliki sarana dan prasarana yang memadai untuk mendukung proses pembelajaran daring, seperti misalnya tidak memiliki ponsel pintar yang kompatibel dengan belajar online, juga akses internet yang tidak dimiliki.

3. Tingkat stress atau gangguan psikologi anak meningkat karena kurangnya pemahaman terhadap metode belajar online, proses belajar yang dianggap sulit, tugas yang menumpuk, kesulitan dalam mengakses tugas yang diberikan.

4. Proses interaksi sosial jadi lebih terbatas bahkan cenderung tidak terjadi karena adanya pelarangan untuk berkumpul atau berkerumun bersama teman atau tidak bisa sekolah tatap muka sehingga tidak bisa bertemu teman.

\section{b. Dampak Sosial Terhadap Orang Dewasa/ Orang Tua}

Selain pada anak-anak yang merupakan siswa atau mahasiswa, hasil penelitian pun menunjukan adanya dampak sosial terhadap para orangtua akibat COVID-19 terlebih setelah pemberlakukan PSBB. Beberapa dampak tersebut adalah:

1. Peningkatan jumlah pengangguran akibat diberlakukannya PHK (Putus Hubungan Kerja) oleh pihak pabrik maupun perusahaan

2. Sebanyak $54 \%$ pekerja laki-laki yang berhenti bekerja dan $56 \%$ perempuan yang mengalami hal serupa

3. Banyak orangtua yang mengeluh akibat diberlakukannya belajar daring sebab hampir $80 \%$ segala tugas harus dikerjakan oleh para orangtua, terlebih bagi orangtua yang anak-anaknya berada di pendidikan sekolah dasar.

4. Tingkat perceraian meningkat, menurut Sutiaji selaku Wali Kota Malang, hingga September 2020 setidaknya ada 2 ribu kasus perceraian yang terjadi di Kota Malang. Selain karena faktor ketidakcocokan, alasan lainnya adalah karena masalah ekonomi yang semakin sulit sebab pendemi. Alasan lainnya adalah karena adanya tindak kekerasan yang dialami oleh pihak perempuan. (jppn.com, 20/10/2020)

5. Kurangnya interaksi sosial yang dilakukan antar masyarakat sebab pandemi terjadi, seperti tidak lagi melangsungkan ibadah berjamaah di tempattempat ibadah umum (Masjid), tidak adanya kegiatan perkumpulan masyarakat, tidak diadakannya kegiatan ketika hari-hari besar seperti peringatan Hari Kemerdekaan pada bulan Agustus lalu, dan tingkat komunikasi atau silaturahmi antar keluarga jauh jadi menurun akibat tidak diperbolehkannya pulang kampung.

\section{c. Dampak Budaya}

Adapun dampak COVID-19 terhadap kehidupan sosial dan berbudaya masyarakat di Kota Malang menjadi sebagai berikut:

1. Perubahan cara belajar-mengajar di Kota Malang yang biasanya secara langsung atau tatap muka, beralih sistem menjadi via daring dan memanfaatkan berbagai media sosial seperti WhatsApp, Email, hingga aplikasi Tik Tok

2. Bisnis atau usaha masyarakat di bidang online shop jadi lebih tinggi seperti dengan memanfaatkan penjualan lewat media sosial atau marketplace 
online, terlebih ketika diberlakukan penutupan kedai-kedai atau cafe di lingkungan masyarakat

3. Silaturahmi online yang mulai semarak terjadi di mana-mana, bahkan hingga adanya proses akad maupun resepsi pernikahan yang dilakukan secara online

4. Di Kota Malang, beberapa masyarakat pun mengalami panic buying atau pembelian bahan makanan secara berlebihan ketika pandemi karena dikhawatirkan akan terjadi krisis pangan. Termasuk juga beberapa alat kesehatan seperti pendeteksi suhu tubuh, masker, hingga alat tes covid.

5. Meskipun terjadinya panic buying namun tingka konsumsi masyarakat di Kota Malang menurun, baik karena kurangnya pemasukan untuk memenuhi kebutuhan harian, maupun sebagai sikap berjaga-jaga karena dikhawatirkan akan terjadinya krisis pangan.

\section{d. Dampak Sosial-Budaya terhadap Pemerintah}

Tak hanya dirasakan oleh masyarakat, pemerintahan di Kota Malang pun ikut merasakan dampak dari kehadiran COVID-19 sebagai pandemi global. Beberapa dampak tersebut adalah:

1. Perubahan metode kerja pemerintah yang lebih terbatas karena untuk meminimalisir penyebaran virus

2. Adanya kenaikan tingkat stress karena pemerintah perlu memberlakukan kebijakan baru ketika pandemi berlangsung

3. Munculnya berita-berita hoax atau disinformasi yang memicu pemerintah harus lebih ekstra dalam mengupayakan penekanan terhadap informasi yang beredar agar tidak banyak meluas berita hoax tersebut

4. Prof. Arry menuturkan adanya ancaman pandemi terhadap stabilitas pemerintahan karena muncul sebuah opini publik akan ketidakpercayaannya terhadap pemerintah yang bisa mengikis legitimisi pemerintahan (unpad.ac.id)

5. Pemerintah mulai memberlakukan banyak kebijakan baru selama pandemi, dari mulai pembatasan sosial, hingga pemberian bansos (bantuan sosial) berupa sembako maupun uang kepada masyarakat terdampak pandemi khususnya di Kota Malang

6. Mulai dibuatnya lembagai layanan umum masyarakat untuk membantu masyarakat dalam mengatasi berbagai keluhan atau masalah yang terjadi akibat COVID-19

\section{e. Dampak Sosial-Budaya bagi Tenaga Kesehatan}

Dampak lain dirasakan juga oleh para tenaga kesehatan yang pada masa pandemi bertugas menjadi garda terdepan. Adapun beberapa dampak COVID-19 yang dirasakan sebagaimana berikut:

1. Kesulitan dalam melakukan hubungan sosial dengan keluarga karena pihak tenaga kesehatan lebih berpotensi untuk menularkan virus ke masyarakat

2. Adanya penilaian negatif dari masyarakat yang diterima oleh tenaga kesehatan sehingga seringkali memicu pengasingan, atau tidak diterimanya tenaga kesehatan di lingkungan masyarakat, bahkan di kampung halamannya sendiri 
3. Perubahan pola kerja dan waktu kerja yang lebih tinggi karena lonjakan pasien yang terkonfirmasi positif COVID-19

\section{Strategi Penanganan Dampak Sosial-Budaya COVID-19 di Kota Malang}

Tujuan lain dari penelitian adalah untuk mengetahui bagaimana strategi yang bisa dilakukan untuk menangani dampak sosial budaya yang disebabkan oleh COVID-19 di Kota Malang. Maka dari penelitian ini, penulis bisa mendapatkan beberapa poin strategis yang bisa dijadikan konsep awal untuk membantu menangani dampak sosial budaya yang terjadi di masyarakat Kota Malang, umumnya masyarakat di Indonesia. Rizqon (2020) mengatakan bawa dalam langkah menangani dampak Covid-19, tentunya sseluruh steakholders harus harus saling bahu membahu dalam memberikan penanganan yang tepat. Kondisi ini pun tidak boleh terlepas pandang dari setiap kebijakan pemerintah dan bagaimana pelaksanaan operasionalisasi di lapangan. Di Kota Malang sendiri, terdapat sebuah lembaga yang dianggap harus mampu menyelesaikan berbagai permasalah di masyarakat.

Menurut portal online Malang Times, Pemkot Malang sendiri menargetkan adanya 17 layanan di pemerintahan yang akan diubah menjadi Badan Layanan Umum Daerah (BLUD). Perubahan status kelembagaan itu dimaksudkan untuk memberikan layanan yang maksimal kepada masyarakat dengan lebih cepat dan mudah terhadap permasalahan apapun yang ada di masyarakat kota Malang. Beberapa lembaga yang diubah seperti RSUD Kota Malang sebagai rumah sakit utama rujukan akan kasus COVID-19, sisanya adalah 16 puskesmas yang dijadikan layanan khusus dalam penanganan awal penyebaran virus corona di Kota Malang. Dimana 6 puskesmasnya sudah menyediakan layanan rawat inap yang terakreditasi. Tentunya atas pemberlakukan tersebut, bisa menjadi sarana dalam mengurangi permasalahan yang terjadi di masyarakat akibat dampak sosial budaya karena COVID-19 secara lebih tepat dan cepat.

Selain itu, ada beberapa poin strategis yang penulis temukan dari hasil penelitian berdasarkan beberapa masalah yang ada sebagai upaya penanganan dampak COVID-19 sebagaimana berikut ini: (1) mengurasi mobilitas masyarakat yang diartikan sebagai gerak sosial atau perpindahan masyarakat dari suatu tempat ke tempat lain. Kebanyakan proses penyebaran virus COVID-19 terjadi akibat adanya kontak langsung antar pasien positif dengan masyarakat sehat. Pemerintah sendiri, sudah melakukan upaya pengurangan mobilitas masyarakat dengan penerapan Pembatasan Sosial Berskala Besar (PSBB) namun hal tersebut pun memicu masalah-masalah baru. Maka dari itu perlu dilakukannya PSBB tertarget. Maksudnya, pembatasan sosial ini hanya ditujukan pada sektor-sektor terbesar pemicu penyebaran saja. (2) mengadakan perlindungan UKM karena sejak adanya pengurangan mobilitas masyarakat, pihak-pihak yang memiliki usaha kecil menengah mengalami penurunan pendapatan. Baik berupa dukungan transisi dari media pemasaran offline ke online, bantuan dana dan sarana prasana yang tersebar secara tepat sasaran. (3) mengadakan program pasar tradisional yang sehat agar tetap memberikan kebutuhan masyarakat akan pangan dan kebutuhan sehari-hari juga membuat para pedagang di pasar tradisional tetap mendapatkan penghasilan. (4) diberlakukannya program bantuan sosial atau dana bantuan bagi masyarakat, 
namun masih banyak yang tidak menerimanya sehingga perlu pengolahan data penerima agar bantuan bisa tepat sasaran. (5) menyediakan sarana prasarana yang memadai bagi para anak-anak atau pihak terkait pendidikan untuk memaksimalkan kondisi pendidikan di era pandemi (6) melakukan sosialisasi dengan lebih tertarget dan mengena kepada masyarakat agar terhindar dari disinformasi yang bisa memperburuk keadaan dan hubungan sosial antara masyarakat juga pemerintah.

\section{KESIMPULAN}

Berdasarkan penelitian yang telah dilakukan, maka secara umum dapat disimpulkan bahwa penyebaran kasus COVID-19 di Kota Malang setiap bulannya mengalami peningkatan. Baik untuk kasus terinfeksi positif maupun pasien yang meninggal, juga pasien-pasien yang berhasil sembuh dan ketika melakukan tes sudah negatif virus corona. Akibat tingginya penyebaran virus corona, maka pemerintah Indonesia maupun pemerintah daerah Kota Malang melakukan pembatasan akses masuk atau ke luar kota Malang dengan pemberlakukan Pembatasan Sosial Berskala Besar, disusul dengan penutupan sementara sekolahsekolah maupun kampus di kawasan Kota Malang, penutupan sementara beberapa kantor atau tempat makan, hingga penutupan sementara tempat peribadatan seperti masjid untuk menghindari kegiatan ibadah berjamaah oleh masyarakat, beserta pemberlakukan kebijakan masyarakat agar selalu di rumah saja. Dari beberapa kebijakan dan pemberlakukan tersebut, memicu adanya masalah atau dampak sosial-budaya yang dirasakan oleh masyarakat dan beberapa pemangku kepentingan di Kota Malang, dimana beberapa dampak tersebut diformulasikan ke dalam beberapa poin berikut:

1. Pada anak-anak seperti siswa atau mahasiswa, banyak dampak sosial yang dirasakan dari mulai kesulitan ketika melakukan sekolah online, kesulitan dalam mengerjakan atau mengakses tugas, dan kesulitan untuk berkumpul atau bermain bersama teman.

2. Begitu juga pada orangtua atau masyarakat lainnya, dimana dampak sosial yang dirasakan seperti tingkat perceraian yang tinggi, tingkat pengangguran yang juga melonjak tinggi, kekerasan pada wanita dan tingkat krimininalitas yang meningkat, serta perubahan pola interaksi antar warga masyarakat

3. Pada kultur atau kebudayaan masyarakat Kota Malang pun mengalami perubahan, seperti pengurangan kegiatan bahkan pembatalan kegiatan masyarakat, ibadah berjamaah di tempat ibadah umum, tingkat sosialisasi masyarakat secara langsung yang semakin berkurang, media komunikasi berubaha, hingga beberapa kondisi baru seperti kepanikan dan tingkat stress yang jadi lebih tinggi.

4. Bagi pemerintah, dampak sosial yang dirasakan adalah pekerjaan yang semakin ekstra harus dilakukan serta banyak pengubahan kebijakan yang harus dilakukan, bahkan hal tersebut memicu adanya tingkat stabilitas pemerintahan yang cenderung ke arah negatif

5. Dampak sosial lainnya dirasakan juga oleh para tenaga kesehatan, bahkan pihak tenaga kesehatan merasa diasingkan oleh masyarakat sekitar sebab pihaknya menjadi orang paling berpotensi menularkan virus 
Dari beberapa dampak tersebut, maka perlu adanya upaya penanganan atau upaya dalam meminimalisir setiap dampak yang terjadi. Di Kota Malang, untuk meminimalisir hal tersebut, pemerintah sudah menyediakan sebuah lembaga umum daerah yang memberikan layanan khusus untuk penanganan masalah COVID-19. Sehingga masyarakat bisa mendapatkan bantuan atau pertolongan secara langsung, tepat dan cepat melalui lembaga tersebut. Selain itu, ada juga beberapa upaya yang dilakukan seperti dengan mengurangi mobilitas masyarakat, pemberdayaan UKM agar pemasukan masyarakat tetap terkontrol, pembuatan pasar tradisional yang sehat, adanya bantuan sosial berupa dana atau prasarana dari pemerintah, dan melakukan sosialisasi yang lebih gencar, tertarget serta efektif untuk menyelaraskan dukungan pemerintah terhadap masyarakat selama pandemi berlangsung.

\section{DAFTAR PUSTAKA}

Anung. (2020). Pengaruh Kebijakan Social Distancing Pada Wabah COVID-19 Terhadap Kelompok Rentan di Indonesia. Jurnal Kebijakan Kesehatan Indonesia. 9 (2), 62

De Salazar, PM. (2020). Using predicted imports of 2019-nCoV cases to determine location that may not be indentifying all imported cases. Available on https://doi.org/10.1101/2020.02.04.20020495

Dito. (2020). Dampak Pandemi COVID-19 Terhadap Perekonomian Indonesia. Jurnal Benefita. Universitas Sumatera Utara. 5 (2), 213-214

Enda. (2010). Ilmu Perilaku Kesehatan. Jakarta: Rineka Cipta

Ikfina. (2020). Dampak Pandemi Covid-19 Dalam Perspektif Gender Di Indonesia. Jurnal Kependudukan Indonesia. Badan Pusat Statistik Papua. 39-40.

Informasi COVID-19 Pemerintah Provinis Jawa Timur. Diakses pada 26 Oktober 2020 dari https://infocovid19.jatimpemprov.go.id

Kementrian Kesehatan Republik Indonesia. (2020). Peraturan Menteri Kesehatan Republik Indonesia Nomor 9 Tahun 2020 tentang Pedoman Pembatasan Sosial Berskala Besar Dalam Rangka Percepatan Penanganan Corona Virus Disease 2019 (COVID-19. Jakarta: Kemenkes RI

Kompas Surabaya (2020). Pabrik Sampoerna Ditutup Setelah 2 Karyawan Positif COVID-19 diakses pada 26 Oktober 2020 dari https://surabaya.kompas.com/read/2020/04/30/11210601/pabriksampoerna-surabaya-ditutup-setelah-2-karyawan-positif-covid19?page $=$ all

Malang Times. (2020). Pemkot Malang Target 17 Layanan jadi Badan Layanan Umum Daerah. Diakses pada 27 Oktober 2020 Dari https://malangtimes.com/amp/baca/28904/20180629/145134/pemkotmalang-target-17-layanan-jadi-badan-layanan-umum-daerah

Michael, Hidayat. (2020). Dampak Coronavirus Terhadap Ekonomi Global. Bank Indonesia. Diakses pada 27 Oktober 2020 dari https://www.bi.go.id/id/publikasi/ekonomi-keuangan-kerjasamainternasional/Documents/Bab_5_Artikel_1_2020.pdf

Pusat Bahasa Indonesia. Kamus Besar Bahasa Indonesia Digital. Available at https://kbbi.web.id 
Ranjabar. (2006). Sistem Sosial Budaya Indonesia: Suatu Pengantar. Bogor: PT Ghalia Indonesia.

Republika. (2020). Khofifah Ingatkan Dampak Sosial Ekonomi dari Wabah COVID-19. Diakses pada 26 Oktober 2020 dari https://republika.co.id/berita/q7ug32384/khofifah-ingatkan-dampaksosialekonomi-dari-wabah-covid19

Rizqon. (2020). Dampak COVID-19 pada Pendidikan di Indonesia: Sekolah, Keterampilan, dan Proses Pembelajaran. Jurnal Sosial dan Budaya Syar'i. Universitas Kebangsaan Malaysia. 7 (5), 396-397

Sugiyono. (2013). Metode Penelitian Kuantitatif, Kualitatif dan R\&D, Bandung: Alfabeta

World Health Organization. (2020). Naming the coronavirus disease (COVID-19) and the virus causes it. diakses pada 27 Oktober 2020 dari https://who.int/emergencies/diseases/novel-coronavirus-2019/technicalguidence/naming-the-coronavirus-disease-(covid-2019)-and-the-virusthat-causes-it

Worldometer. (2020) Kasus Penyebaran COVID-19 di Indonesia. Diakses pada 26 Oktober $2020 \quad$ dari https://worldometers.info/coronavirus/country/indonesia/ 